\title{
Effect of sintering temperatures on the properties of in-situ copper-niobium-titanium di-boride composites
}

\author{
Azunna Agwo Eze ${ }^{1}$ (D) Emmanuel Rotimi Sadiku ${ }^{1}$ - Williams Kehinde Kupolati ${ }^{2}$. Jacques Snyman ${ }^{2}$. \\ Julius Musyoka Ndambuki ${ }^{2}$. Tamba Jamiru ${ }^{3}$. Mondiu Olayinka Durowoju ${ }^{4}$ Idowu David Ibrahim ${ }^{3}$. \\ Mxolisi Brendon Shongwe ${ }^{1} \cdot$ Dawood A. Desai ${ }^{3} \cdot$ Ronald Machaka $^{5} \cdot$ Khumbulani Mpofu $^{6}$
}

Received: 17 August 2020 / Accepted: 25 November 2020 / Published online: 30 November 2020

(c) Springer Nature Switzerland AG 2020

\begin{abstract}
This work investigated the effect of the sintering temperatures on the densification of the powders, density, relative density, microhardness, coefficient of thermal expansion, and corrosion resistance in sulphuric acid solution environment of copper-niobium-titanium di-boride composite. A $90 \%$ weight of copper, reinforced with a $6 \%$ weight of niobium micro-particles and $4 \%$ weight of titanium-diboride was prepared in powdered form and sintered in two different temperatures of $650^{\circ} \mathrm{C}$ and $700^{\circ} \mathrm{C}$ using the spark plasma sintering method. The crystal phases and the morphologies of both the starting powders and the sintered samples were analyzed by the use of X-ray diffraction with copper Alpha-K radiation and scanning electron microscopy with energy dispersive $\mathrm{X}$-ray spectroscopy. The results show that sintering at a temperature of $700^{\circ} \mathrm{C}$ reduced the displacement rate of the powders with a higher microhardness value of $941 \mathrm{MPa}$ when compared with the sintering temperature of $650^{\circ} \mathrm{C}$, which prolonged the displacement rate of the powders with a lower microhardness value of $827 \mathrm{MPa}$. The sintered samples recorded negative thermal expansion values of $-1.375 \times 10^{-5}{ }^{\circ} \mathrm{C}^{-1}$ and $-7.780 \times 10^{-6}{ }^{\circ} \mathrm{C}^{-1}$ at temperatures of $650{ }^{\circ} \mathrm{C}$ and $700{ }^{\circ} \mathrm{C}$, respectively. The sample sintered at $700^{\circ} \mathrm{C}$ has better micro-hardness and better corrosion resistance in a sulphuric acid environment when compared to the one sintered at $650^{\circ} \mathrm{C}$. This study has shown that the varying of the sintering temperatures has an effect on the properties of the composite under study. The produced composites can be used to control the mechanical and electrical properties, and the thermal expansion of functional materials, such as superconductors, semiconductors, ferroelectrics, magnetic and Mott insulators, etc.
\end{abstract}

Keywords Copper-metal matrix composites spark plasma sintering · Microstructure - Negative thermal expansion . Corrosion in sulphuric acid

\section{Introduction}

Pure copper is a potential material as a substitute for gold $\mathrm{Au}$ ) and silver $\mathrm{( \textrm {Ag } )}$ to produce metal matrix composites, for electrical contacts. This is because of its excellent electrical conductivity and low cost. The service lives of electrical contacts decrease due to their low hardness and the low nature of the operational temperatures of pure copper. To overcome this shortcoming of pure copper, the common route of increasing the strength and operational

Azunna Agwo Eze, ezeaaben@gmail.com | ${ }^{1}$ Institute for Nano-Engineering Research (INER) and Department of Chemical, Metallurgical and Materials Engineering, Tshwane University of Technology, Pretoria, South Africa. ${ }^{2}$ Department of Civil Engineering, Tshwane University of Technology, Pretoria, South Africa. ${ }^{3}$ Department of Mechanical Engineering, Mechatronics and Industrial Design, Tshwane University of Technology, Pretoria, South Africa. ${ }^{4}$ Department of Mechanical Engineering, Ladoke Akintola University of Technology (LAUTEC), Ogbomoso, Oyo State, Nigeria. ${ }^{5}$ Titanium Centre of Competence, Council for Scientific and Industrial Research, Pretoria, South Africa. ${ }^{6}$ Department of Industrial Engineering, Tshwane University of Technology, Pretoria, South Africa. 
temperature of copper, while retaining its excellent conductivity, is to alloy with a member of the body-centered cubic (bcc) structural family of elements, e.g., niobium [1].

Copper-niobium composites have been reported to have excellent mechanical properties [2-4]. It was reported that both the mechanical and electrical conductivity characteristics of copper-niobium, can conveniently and significantly surpass those of its competitive alloys, such as copper-titanium, copper-beryllium, and coppernickel-magnesium $[5,6]$. The increasing research on copper-niobium composites is due to the increasing demand for copper-based composites that have a good combination of excellent mechanical strength, electrical conductivity, and environmentally friendly, unlike copper-cadmium, and copper-beryllium that are harmful to humans and the environment [2]. Copper-niobium alloy has demonstrated a combination of high strength and good electrical conductivity $[2,3,5]$ and thermal conductive stability, at temperatures ranging between 400 and $1000^{\circ} \mathrm{C}$, without disruption [4]. The aforementioned properties would make it possible for copper-niobium to be the preferred candidate material for the fabrication of electrical devices that can withstand mechanical and thermal stresses.

On the other hand, there has been great interest in the production of composites with titanium-diboride, as reinforcing phase. Titanium-diboride has excellent mechanical properties, which when added to a matrix, enhances the overall performance of the resulting composites $[7,8]$. Titanium-diboride is a ceramic material and its excellent mechanical and good conductive properties, predetermine its potential use in various high-temperature applications, especially those including highly corrosive molten salts [9]. To enhance the strength of copper metal matrix composites, some hard additives, e.g., titanium-diboride had been employed [10-15].

In this study, titanium-diboride is added to copper-niobium as a third phase. The addition is expected to enhance the mechanical properties as well as the corrosion resistance of the composites. There are research works that have shown that titanium-diboride behaves like a passive metal in acid and salt environments, due to the formation of a surface oxide film, whose protective power, decreases with temperature $[16,17]$.

The admixture of the three material elements $(\mathrm{Cu}$, $\mathrm{Nb}$, and $\mathrm{TiB}_{2}$ ), during solid-state mixing, showed significant insolubility, since there are large differences in their specific gravities. However, different powdered materials with immiscibility of phases in their solid states should be prepared/fabricated employing powder metallurgy [2, $18]$, hence the use of powder metallurgy route, with spark plasma sintering technique in this study. Spark plasma sintering technique has a lot of advantages over the conventional powder consolidation technique, which includes: fast sintering, lower sintering time with temperature, minimized grain coarsening, prevention of unnecessary reactions between the different phases, effective consolidation, and production of near net-shaped materials [2, 19-23]. In the spark plasma sintering technique, the total punch displacement of the powders is affected by the following parameters such as; the applied pressure, reaction of the products, graphite foil, heating behavior, sintering temperature, and time [24]. In this study, a composite consisting of copper-niobium ( $\mathrm{Cu}-\mathrm{Nb})$ powders, reinforced with titanium-diboride $\left(\mathrm{TiB}_{2}\right)$ powder was produced by using spark plasma sintering technique at two different sintering temperatures of $650{ }^{\circ} \mathrm{C}$ and $700{ }^{\circ} \mathrm{C}$. Attention was, focused on the investigation of the effect of those varying sintering temperatures on the densification of the powders, relative density, microstructures, microhardness, and the coefficient of thermal expansion (CTE) and the corrosion performance of the resultant composite, in an $\mathrm{H}_{2} \mathrm{SO}_{4}$ acid environment, conducted through electrochemical tests. There is no literature information on copper-niobium-titanium-diboride $\left(\mathrm{CuNbTiB}_{2}\right)$ fabricated at two different sintering temperatures, via the spark plasma sintering technique, as well as the effects of varying sintering temperatures on their microstructure, mechanical properties, coefficient of thermal expansion, and corrosion resistance, in an acid solution environment. However, the selection criteria of the composition determined in this study were based on the results obtained on good properties of copper-niobium and copper-titanium diboride of the previous works $[3,4,6,10-14]$.

\section{Experimental procedure}

In the present study, pure copper, niobium, and titaniumdiboride were used as the starting powders. The properties, composition of the mixed powders, purity, particle sizes, and the suppliers of the starting materials are contained in Table 1.

The SEM images of the starting powders are shown in Fig. 1. The contents, of the mixed powders $\left(\mathrm{CuNbTiB}_{2}\right)$ in weight percent ( $w t \%)$, were selected to be; $90 \mathrm{wt} \%$ of $\mathrm{Cu}, 6 \mathrm{wt} \%$ of $\mathrm{Nb}$, and $4 \mathrm{wt} \%$ of $\mathrm{TiB}_{2}$. The powders were inserted into a plastic cylinder, together with aluminum balls to enhance the homogenous mixture and reduce agglomeration of the powders. The powders were mixed for two (2) hours in a T2F tubular shaker mixer with a rotational speed of 72 revolutions per minute. After mixing, a spark plasma sintering machine, HPDS model, FCT system made in Germany was then used to sinter the admixed powders. The sintering was done at two different sintering temperatures of $650^{\circ} \mathrm{C}$ and $700^{\circ} \mathrm{C}$, with a heating rate of $50^{\circ} \mathrm{C} / \mathrm{min}$, holding time (dwell time) of 
Table 1 Summary of the properties, compositions, suppliers, purities, and particles size of the starting materials

\begin{tabular}{|c|c|c|c|}
\hline Elements & $\mathrm{Cu}$ & $\mathrm{Nb}$ & $\mathrm{TiB}_{2}$ \\
\hline Density $\left(\mathrm{g} / \mathrm{cm}^{3}\right)$ & 8.96 & 8.57 & 4.50 \\
\hline Melting point $\left({ }^{\circ} \mathrm{C}\right)$ & 1083.4 & 2477 & $>3000$ \\
\hline Hardness Vickers & $369 \mathrm{MPa}$ & $1320 \mathrm{MPa}$ & $33343 \mathrm{MPa}$ \\
\hline $\mathrm{CTE}$ at $20^{\circ} \mathrm{C}$ & $17 \times 10^{-6}{ }^{\circ} \mathrm{C}^{-1}$ & $7.1 \times 10^{-6}{ }^{\circ} \mathrm{C}^{-1}$ & $8 \times 10^{-6}{ }^{\circ} \mathrm{C}^{-1}$ \\
\hline $\begin{array}{c}\text { Composition of } \mathrm{CuNbTiB}_{2} \\
\text { mixed powders (wt\%) }\end{array}$ & 90 & 6 & 4 \\
\hline Suppliers & Alfa Aesar & Alfa Aesar & $\begin{array}{l}\text { Grade F supplied by } \\
\text { Herman C Starck, Belin, } \\
\text { German }\end{array}$ \\
\hline Purity (\%) & 99 & 99.8 & 99 \\
\hline Particle sizes & $44 \mu \mathrm{m}$ & $44 \mu \mathrm{m}$ & $75 \mu \mathrm{m}$ \\
\hline
\end{tabular}
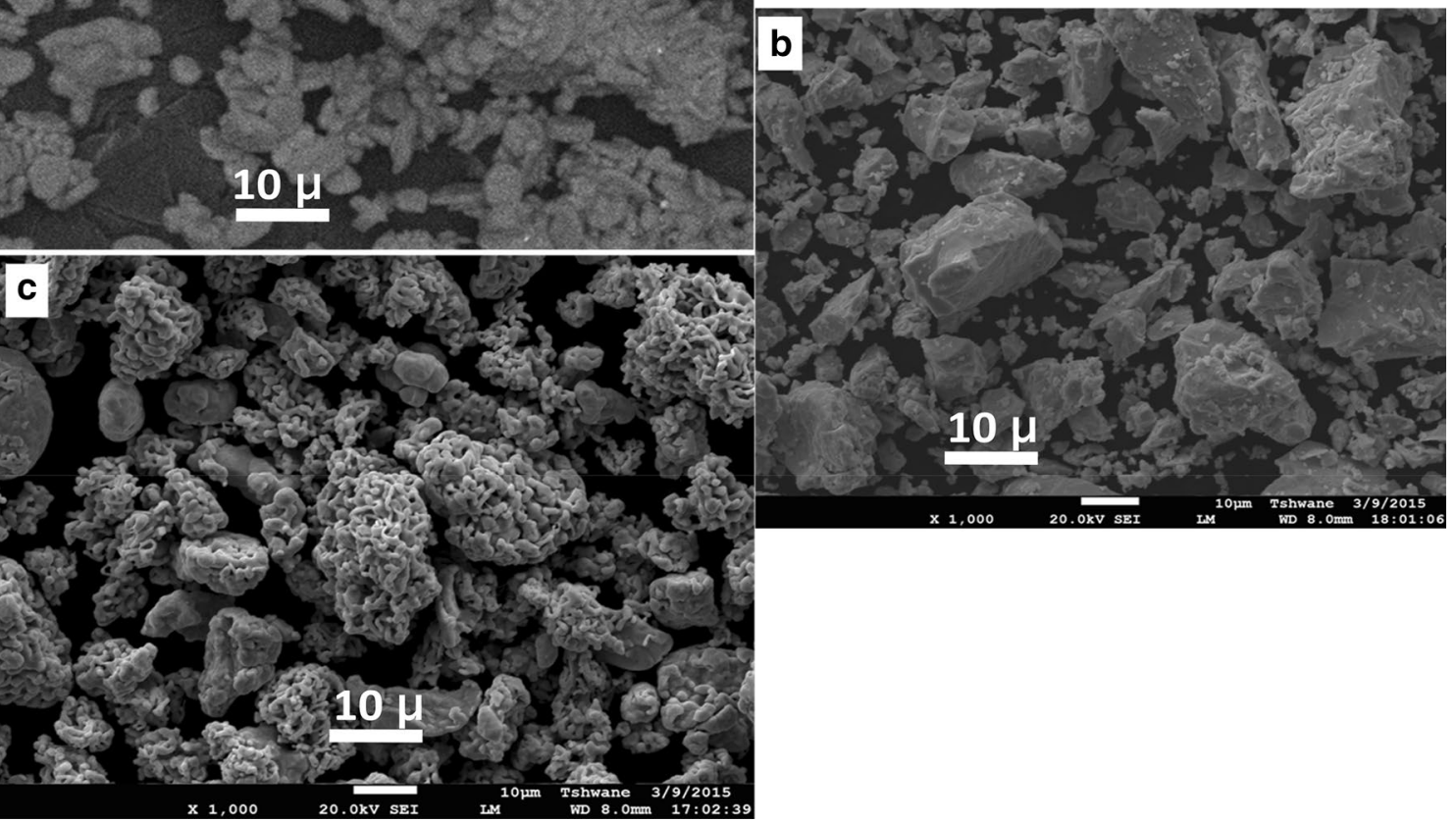

Fig. 1 Shows SEM images of the starting powder: $\mathbf{a} \mathrm{TiB}_{2}, \mathbf{b} \mathrm{Nb}$ and $\mathbf{c} \mathrm{Cu}$

$5 \mathrm{~min}$, and at a pressure of $50 \mathrm{MPa}$. The displacement of the piston during the heating of the powders created a linear shrinkage, and the recorded values were used in Eq. 1 to obtain the values of the CTE [8].

$C T E=\frac{\varepsilon T 1-\varepsilon T 2}{T 1-T 2} \frac{1}{100}$

Where: $\varepsilon_{\mathrm{T} 1}$ represents the shrinkage after cooling in \%,

$\varepsilon_{\mathrm{T} 2}$ represents the shrinkage at the ending of the dwell in \%,
$\mathrm{T}_{1}$ represents the temperature after cooling in ${ }^{\circ} \mathrm{C}$ and $\mathrm{T}_{2}$ represents the temperature at the ending of the dwell in ${ }^{\circ} \mathrm{C}$.

$\mathrm{X}$-ray diffraction (XRD) and the field emission scanning electron microscopy (FESEM, JSM-7600F, Jeol, Japan), equipped with energy dispersive $x$-ray spectrometer (EDS), were used to characterize the structural and morphological characteristics of the starting powders and the sintered samples.

The densities were measured according to the Archimedes principle. The relative densities were calculated 
regarding the theoretical density of ${ }_{90} \mathrm{Cu}_{6} \mathrm{Nb}_{4} \mathrm{TiB}_{2}$ by using the rule of mixture.

The microhardness of the sintered samples was determined by the EMCO Durascan Vickers micro-hardness tester, under a load of $100 \mathrm{gf}$ and a dwelling time of $15 \mathrm{~s}$. The measurement was performed five (5) times from random locations on the central region of the polished cross section, and the average values were then considered.

The corrosion resistance of the sintered $\mathrm{CuNbTiB}_{2}$ was analyzed. The specimens for corrosion testing were prepared by attaching an insulated copper wire, by using aluminum tape to one face of the specimen, and coldmounted in an epoxy resin, and the opposite face was ground and polished. The open circuit potential (OCP) and potentiodynamic polarization tests were conducted to obtain information on the corrosion behavior of the sintered samples in a mole of sulphuric acid $\left(\mathrm{H}_{2} \mathrm{SO}_{4}\right)$ environment. The corrosion experiments were carried out by using an Auto-lab potentiostat (PasTAT30). All the experiments were carried out by using a 3-electrode corrosion cell setup with $\mathrm{Ag} / \mathrm{AgCl}$ reference electrode, saturated with $3 \mathrm{~mol} \mathrm{AgCl}$, a graphite rod as the counter electrode, and the specimen as the working electrode. Tests were conducted at room temperature $\left(23 \pm 2{ }^{\circ} \mathrm{C}\right)$, whereby the open circuit potential stabilization was run for one (1) hour and polarization measurements were carried out at a scan rate of $0.002 \mathrm{~V} / \mathrm{s}$, with potential initiated at $-1.5 \mathrm{~V}$ to $+1.5 \mathrm{~V}$.

\section{Results and discussion}

\subsection{Powder characterization}

The SEM of the starting powders is shown in Fig. 1. The particle sizes of the starting powders are shown contained in Table 1, and the particle shapes of the powders are presented in Figs. 1 and 2. The $\mathrm{TiB}_{2}$ particles shape are irregular (Figs. $1 \mathrm{a}$ and $2 \mathrm{a}$ ), Nb powders have flak-like shapes (Figs. $1 \mathrm{~b}$ and 2b), while Cu powders have agglomeration with some rounded shape particles distributed among them (Figs. 1c and 2c). The elemental composition of the starting powders is presented in the table attached to Fig. 2. The EDS result (Fig. 2) shows that all the powders of the starting powders were pure as-received materials with a little amount of oxygen present in each of them. In Fig. $2 \mathrm{a}$, the $\mathrm{TiB}_{2}$ powder is found to be composed of: boron (B: $39.08 \mathrm{wt} \%$ ), oxygen (O: $11.69 \mathrm{wt} \%$ ), and titanium (Ti: $49.23 \mathrm{wt} \%$ ). In Fig. $2 \mathrm{~b}$, the niobium powder is found to be composed of; oxygen (O: $4.32 \mathrm{wt} \%$ ), and niobium ( $\mathrm{Nb}: 95.68 \mathrm{wt} \%$ ), while the copper powder is found to be composed of oxygen (O: $2.99 \mathrm{wt} \%)$, and copper (Cu: $97.01 \mathrm{wt} \%)$. The presence of oxygen might have resulted in the partial oxidation of the elements of the starting powders, to form their respective oxides.
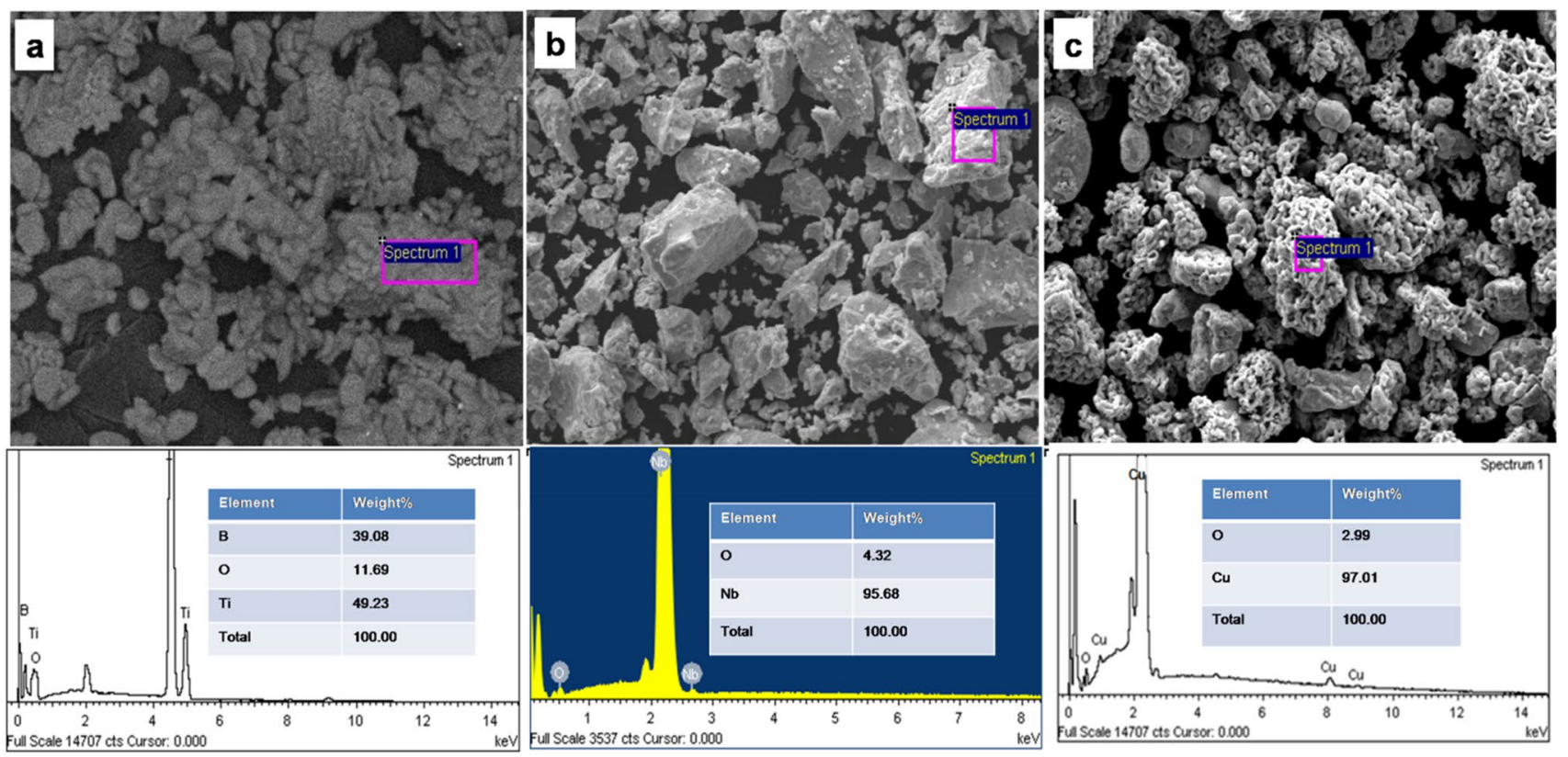

Fig. 2 SEM images and EDS analysis of the starting powders with their elemental compositions: $\mathbf{a} \mathrm{TiB}_{2}, \mathbf{b} \mathrm{Nb}$ and $\mathbf{c} \mathrm{Cu}$

\section{SN Applied Sciences}




\subsection{Displacement rate as a function of the temperature of the admixed powder during sintering}

The $\mathrm{CuNbTiB}_{2}$ admixed powders were sintered at two different sintering temperatures, while the other sintering parameters, such as pressure, holding time, and heating rate, were constant of $50 \mathrm{MPa}, 5 \mathrm{~min}$, and $50^{\circ} \mathrm{C} / \mathrm{min}$, respectively. The displacement rate, as a function of temperature, for the CuNbTiB 2 composites, is shown in Fig. 3 . The variation of the sintering temperatures has a perceptible effect on the densification rate of the composite. According to the work of Diouf and Molinari [25], which stated that under the application of low initial pressure, the densification is due to particle rearrangement, localized deformation, bulk deformation, and neck growth, and these phenomena were presented as four peaks. In this study, one weak peak at $350^{\circ} \mathrm{C}$ is observed (Fig. 3a) from the sample sintered at $650^{\circ} \mathrm{C}$. This peak can be identified as the point, where there was particle rearrangement, which occurred with the maximum displacement rate at a low temperature of $350{ }^{\circ} \mathrm{C}$. Rearrangement occurs through the relative movement of the particles and this is opposed by the inter-particle friction at the contact points [25]. In Fig. 3b, densification occurred between $400{ }^{\circ} \mathrm{C}$ and $700{ }^{\circ} \mathrm{C}$. The phenomena that are responsible for densification, according to Diouf and Molinari [25] are overlapped in Fig. 3b, where one broad peak at $400-700^{\circ} \mathrm{C}$, was observed. In Fig. 3, the arrow that pointed rightward indicates the path of heating (displacement rate with an increase in temperature). While the arrow pointing leftward indicates the cooling of the sample after the maximum sintering temperatures. However, the extinction of the peaks in this study, which are responsible for the

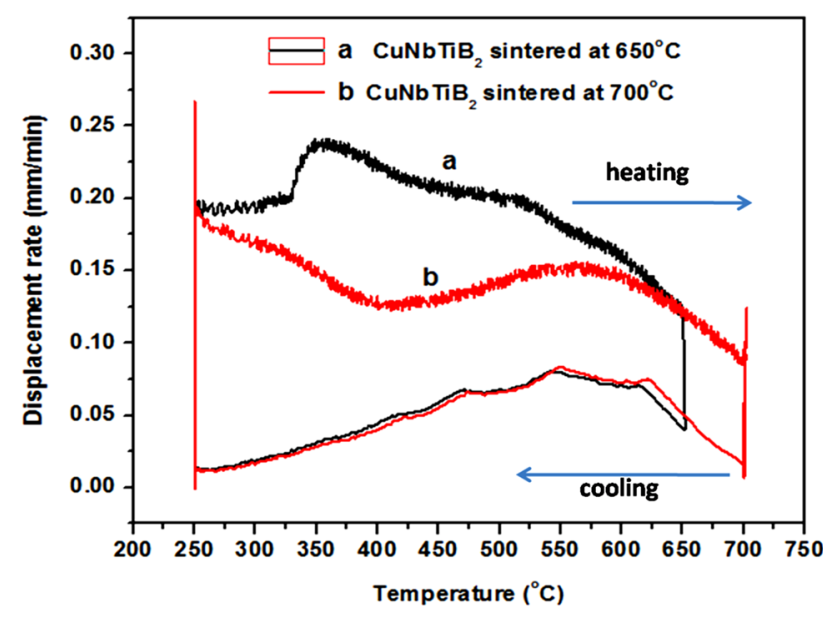

Fig. 3 Densification rate as a function of temperature for $\mathrm{CuNbTiB}_{2}$ composite: a sample sintered at $650{ }^{\circ} \mathrm{C}$ and $\mathbf{b}$ sample sintered at $700{ }^{\circ} \mathrm{C}$

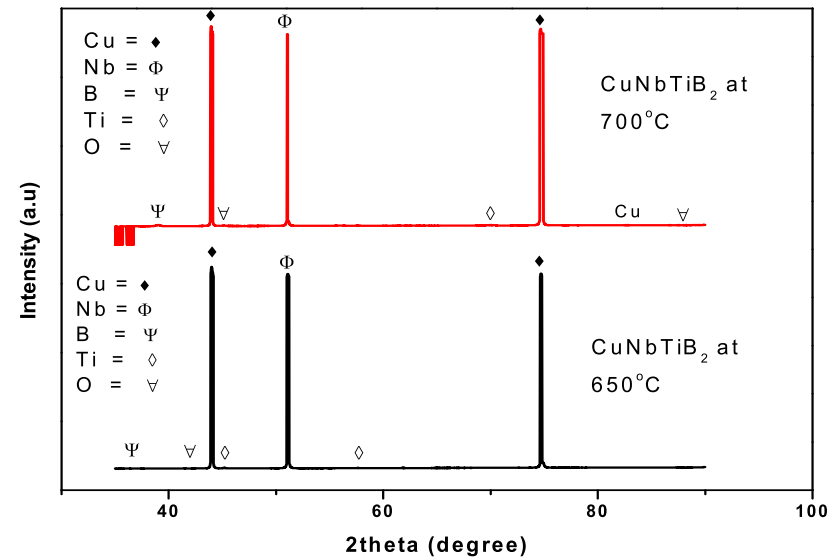

Fig. 4 XRD analysis of $\mathrm{CuNbTiB}_{2}$ sintered composite at $650{ }^{\circ} \mathrm{C}$ and $700{ }^{\circ} \mathrm{C}$

proper densifications, according to the work of Diouf and Molinari [25], could be attributed to the presence of dissolved oxygen in the samples, as can be seen in the SEM and EDS images (Figs. 5, 6, 7, 8, 9, 10). The presence of oxygen in the sintering samples, during the spark plasma sintering process, hinders the densification mechanism [26]. The poor densification observed in this study, due to the presence of oxygen, was the prime cause of the low density and relative density obtained. Also, it is seen that the selected temperature and sintering time are also effective among the factors that determined the densifications and densities of the sintered samples. Also, the presence of $\mathrm{Nb}$ and $\mathrm{TiB}_{2}$ as the reinforcement agents to $\mathrm{Cu}$, in this study, is believed to be the cause of the low densification experienced, during the sintering of $\mathrm{CuNbTiB}_{2}$ composite. Other researchers had confirmed that the higher the reinforcement content, the higher the probability of clusters

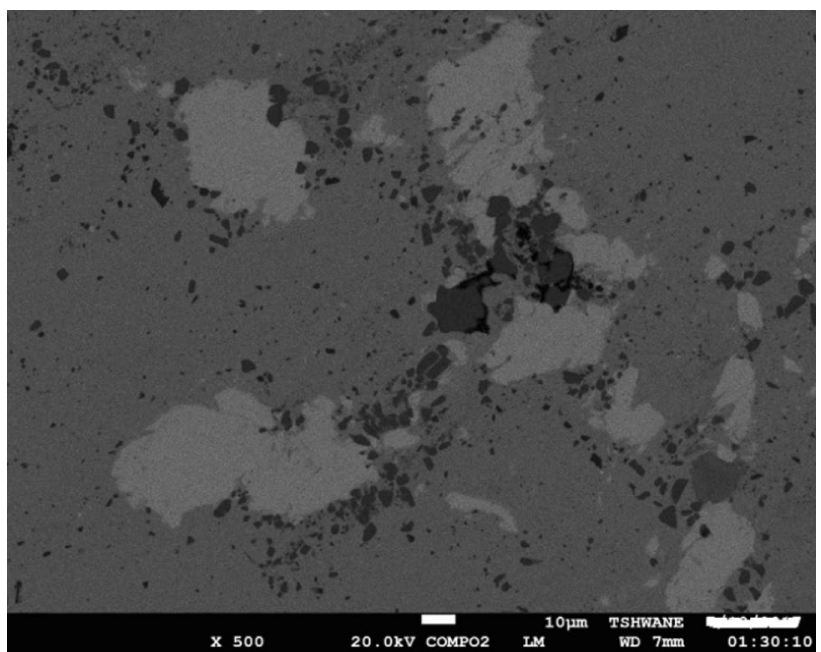

Fig. 5 SEM image of $\mathrm{CuNbTiB}_{2}$ composite sintered at $650^{\circ} \mathrm{C}$ 


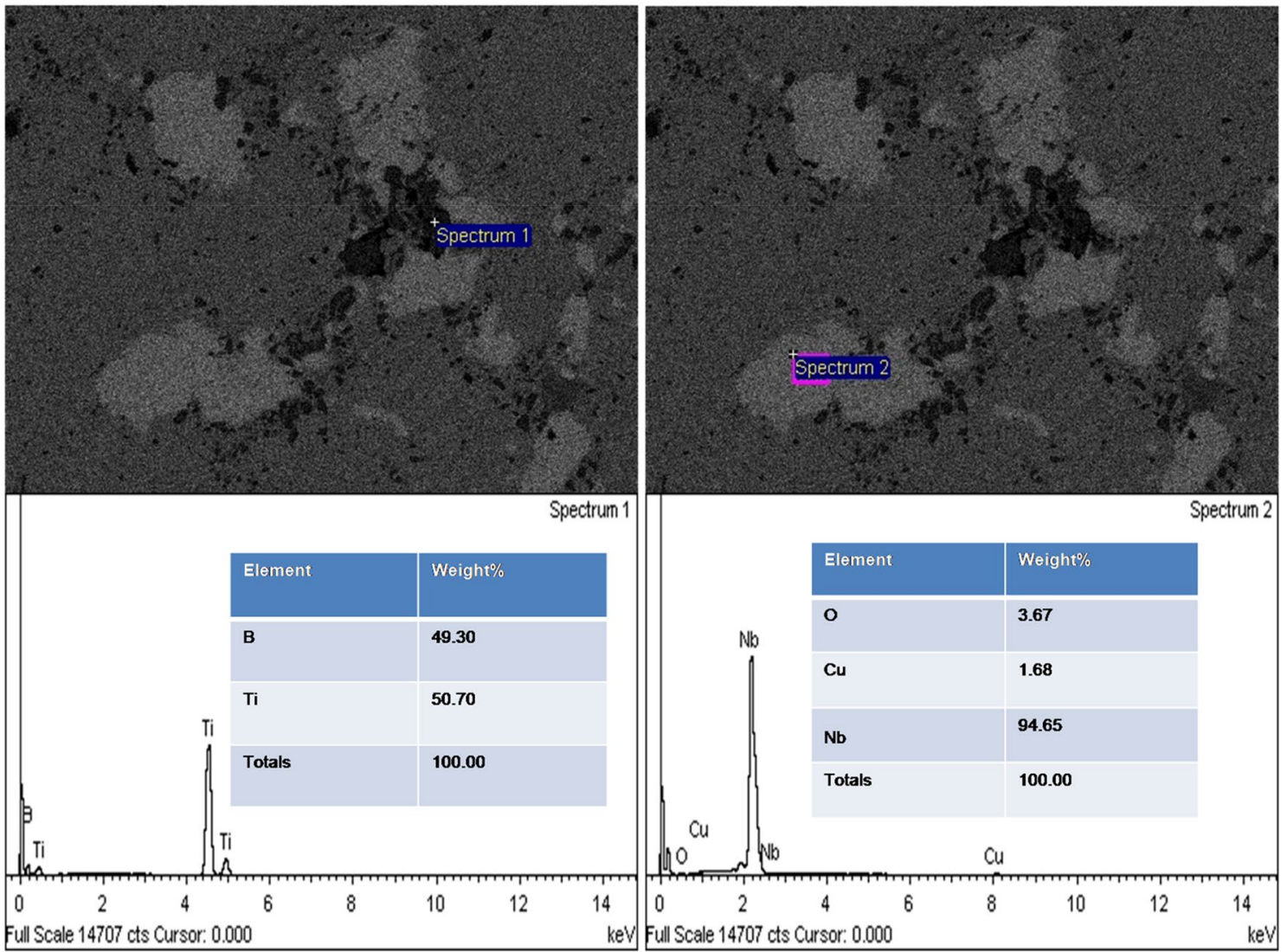

Fig. 6 SEM images and EDS analysis of $\mathrm{CuNbTiB}_{2}$ composite, sintered at $650^{\circ} \mathrm{C}$ showing 1 and 2 peaks

and particle defects and consequently, the reduction in the composite densification and hence, in its density [8, 27].

\subsection{X-ray diffraction of the sintered samples}

To classify the phases present or formed when $90 \mathrm{wt} \%$ of $\mathrm{Cu}, 6 \mathrm{wt} \%$ of $\mathrm{Nb}$ and $4 \mathrm{wt} \%$ of $\mathrm{TiB}_{2}$ were sintered as $\mathrm{CuNbTiB}_{2}$ composite, at the sintered temperatures of $650^{\circ} \mathrm{C}$ and $700^{\circ} \mathrm{C}$, the XRD analysis was carried out and it is shown in Fig. 4. The XRD results show the distribution of the phases observed as the composite was sintered at $650^{\circ} \mathrm{C}$ and $700{ }^{\circ} \mathrm{C}$. There are five (5) phases observed in the samples that were sintered at both temperatures, with the peaks of $\mathrm{Cu}$ and $\mathrm{Nb}$ occurring at high intensity. There was no significant shift in the peaks of $\mathrm{Cu}$ and $\mathrm{Nb}$, but oxygen and titanium were observed to have occurred at higher 2theta of the sample sintered at $700^{\circ} \mathrm{C}$. The phases observed in the XRD results (Fig. 4), are the same as the phases in the starting powders (Fig. 2), which are: $\mathrm{Cu}, \mathrm{Nb}$, $\mathrm{B}, \mathrm{Ti}$, and $\mathrm{O}$. These show that the composite was not contaminated with any other foreign material, except oxygen during the spark plasma sintering at both temperatures.

\subsection{SEM and EDS of the sintered samples}

Figures 5, 6, 7, 8, 9, 10 show the SEM images and EDS analysis of the $\mathrm{CuNbTiB}$ composite, sintered at temperatures of $650{ }^{\circ} \mathrm{C}$ and $700{ }^{\circ} \mathrm{C}$. The EDS spectra were used to analyze the chemical composition of dissimilar regions of the $\mathrm{CuNbTiB}_{2}$ composites. The results are summarized in the tables, attached to each EDS graph. Figures 5 and 8 present the high magnification, the SEM images of the sintered composites at $650{ }^{\circ} \mathrm{C}$ and $700{ }^{\circ} \mathrm{C}$, respectively. Figure 6 shows the EDS analysis, indicating the elemental composition, as summarized in a tabular form, for the $\mathrm{CuNbTiB}_{2}$ composites sintered at $650^{\circ} \mathrm{C}$. In Fig. 6 , there are two spectra ( 1 and 2 ) that identify the phases that are present at those points in the matrix. Spectrum 1 in Fig. 6 , identifies the thick black colors that are dispersed in the matrix to be $\mathrm{TiB}_{2}$, which contains: $\mathrm{B}(49.30 \mathrm{wt} \%)$, and $\mathrm{Ti}$ (50.70 wt\%). In spectrum 2 in Fig. 6, it confirms the white dispersed colors to be a high amount of $\mathrm{Nb}$ particles $(94.65$ wt\%), with little presence of $\mathrm{Cu}(1.68 \mathrm{wt} \%)$, and $\mathrm{O}$ (3.67 wt\%). Figure 7 shows spectrum 3 EDS analysis of $\mathrm{CuNbTiB}_{2}$ composite, sintered at $650{ }^{\circ} \mathrm{C}$. Spectrum 3 in Fig. 7 confirms the fact that $\mathrm{Cu}(96.61 \mathrm{wt} \%)$, with a little amount of $\mathrm{O}(3.39 \mathrm{wt} \%)$, were present in that region. Figure 8 shows

\section{SN Applied Sciences}



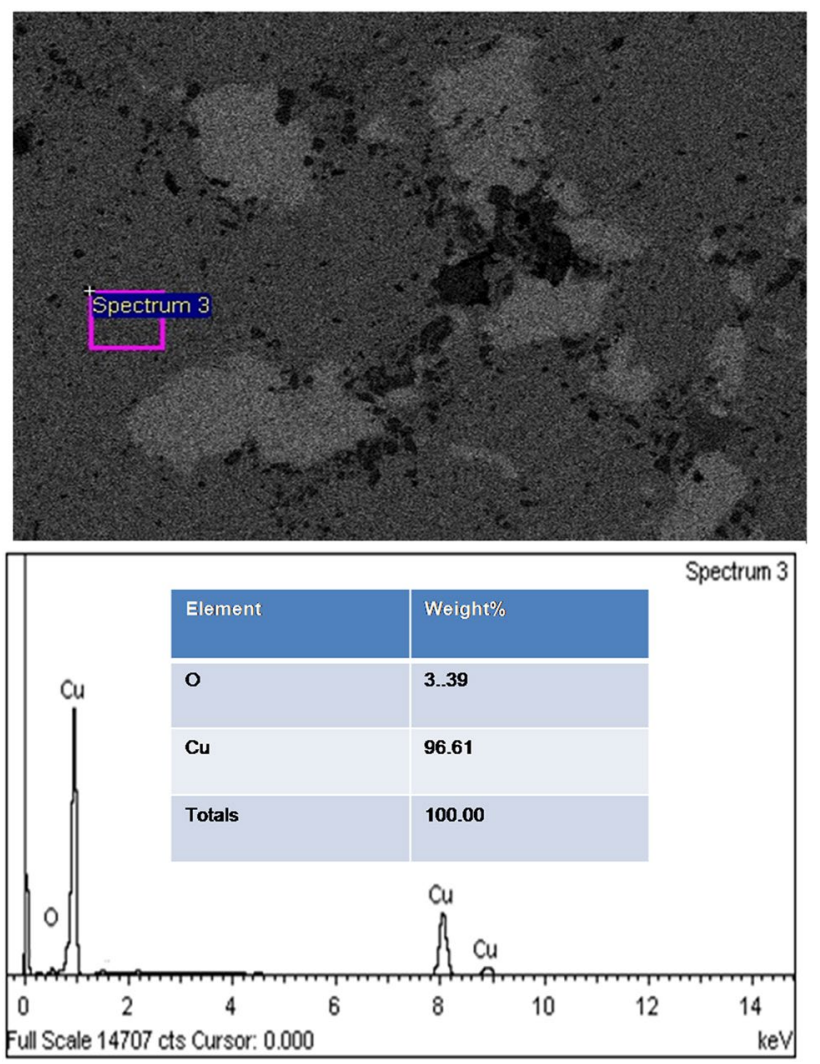

Fig. 7 SEM image and EDS analysis of $\mathrm{CuNbTiB}_{2}$ composite sintered at $650^{\circ} \mathrm{C}$, showing 3 peaks

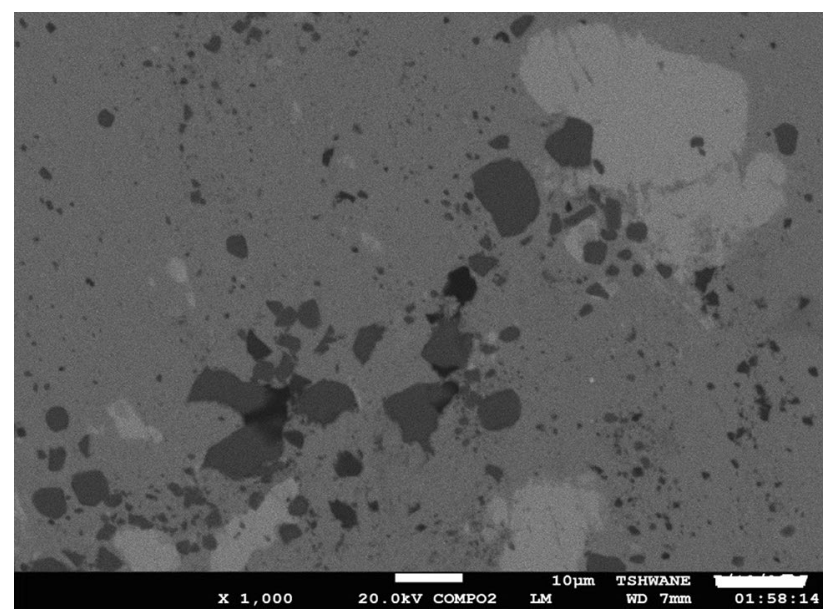

Fig. 8 SEM image of $\mathrm{CuNbTiB}_{2}$ composite sintered at $700{ }^{\circ} \mathrm{C}$

the SEM image of $\mathrm{CuNbTiB}_{2}$ composite, sintered at $700^{\circ} \mathrm{C}$. The EDS analysis with spectra 1 and 2 of the $\mathrm{CuNbTiB}_{2}$ composite, sintered at a temperature of $700{ }^{\circ} \mathrm{C}$, is shown in Fig. 9, while Fig. 10 shows the EDS analysis with spectra 3 and 4 of the $\mathrm{CuNbTiB}_{2}$ composite, sintered at $700^{\circ} \mathrm{C}$. Spectrum 1 in Fig. 9 identifies a large whitish phase to be a high amount of $\mathrm{Nb}(95.44 \mathrm{wt} \%)$ and little amounts of $\mathrm{Cu}$ (1.47 wt\%) and $\mathrm{O}$ (3.09 wt\%). Spectrum 2 in Fig. 9 identifies the dispersed black pigment to be $\mathrm{TiB}_{2}$ with a little amount of $\mathrm{Cu}, \mathrm{Ti}(52.37 \mathrm{wt} \%), \mathrm{B}(46.76 \mathrm{wt} \%)$, and $\mathrm{Cu}(0.87$ $w t \%)$. Spectrum 3 in Fig. 10 identifies a whitish spot to be a high amount of $\mathrm{Nb}(93.74 \mathrm{wt} \%)$ with little amounts of $\mathrm{Cu}$ (2.07 wt\%) and $\mathrm{O}$ (4.18 wt\%), while spectrum 4 in Fig. 10 identifies a tiny black dispersion to be a high amount of $\mathrm{Cu}(94.83 \mathrm{wt} \%)$, with little amounts of $\mathrm{Nb}(2.88 \mathrm{wt} \%)$ and O (2.29 wt\%).

In the sintered composites, sintered at two different temperatures $\left(650^{\circ} \mathrm{C}\right.$ and $700{ }^{\circ} \mathrm{C}$ ), it was observed that oxygen was present everywhere there is the presence of $\mathrm{Nb}$ and $\mathrm{Cu}$. These results confirmed the possibility of having niobium oxide(s) $\left(\mathrm{NbO}_{\mathrm{x}}\right)$ and copper oxide(s) $\left(\mathrm{CuO}_{\mathrm{x}}\right)$ in the composites, sintered at both temperatures, where $x$ could range between 1 and 5 . However, this is strong evidence that confirms the negative thermal expansion (NTE) behavior, found in the $\mathrm{CuNbTiB}_{2}$ composites produced, in this work. It had been reported that $\mathrm{NbO}_{x}$ and $\mathrm{CuO}_{\mathrm{x}}$ are strong candidates for NTE materials [28-31]. The SEM micrographs of the sintered samples sintered at $650^{\circ} \mathrm{C}$ and $700^{\circ} \mathrm{C}$ show uneven dispersion of $\mathrm{Nb}$ and $\mathrm{TiB}_{2}$ particles in the $\mathrm{Cu}$ matrix. The clustered particles of $\mathrm{Nb}$ and $\mathrm{TiB}_{2}$ in the matrix are attributed to the different particle sizes, as well as the different specific gravity of the starting powders. These could make it difficult to have a homogenous mixture of the starting powders during turbulence mixing. However, the admixed powders of the elements, which have different specific gravities, are liable to separate during vibration, flow, or movement [4]. Therefore, this might be the cause for the poor densification (Fig. 3), of the composite, observed during sintering. This effect could as well be attributed to the low density and relative density values obtained (Table 2 ).

\subsection{Density, relative density, and microhardness of the sintered samples}

The values of the final density, relative density, and microhardness of the sintered $\mathrm{CuNbTiB}_{2}$ composites, are summarized in Table 2. In this study, $90 \mathrm{wt} \% \mathrm{Cu}$ was reinforced with $6 \mathrm{wt} \% \mathrm{Nb}$ and $4 \mathrm{wt} \% \mathrm{TiB}_{2}$ powders. With high mass fractions of the reinforcement phase $(6 \mathrm{wt} \%$ $\mathrm{Nb}$, and $\left.4 \mathrm{wt} \% \mathrm{TiB}_{2}\right)$, it is predictable that there will be a high likelihood of powders agglomeration, unsuitable binding of the matrix phase, and possibly for crack development within the sintered composites. From Table 2, it can be seen that the sample that was sintered at $650^{\circ} \mathrm{C}$, has higher density and relative density values of $7.605 \mathrm{~g} / \mathrm{cm}^{3}$ and $88.4 \%$, respectively, when compared with the sintered sample at $700{ }^{\circ} \mathrm{C}$, which has a density and relative density values of $7.556 \mathrm{~g} / \mathrm{cm}^{3}$ and $87.9 \%$, 


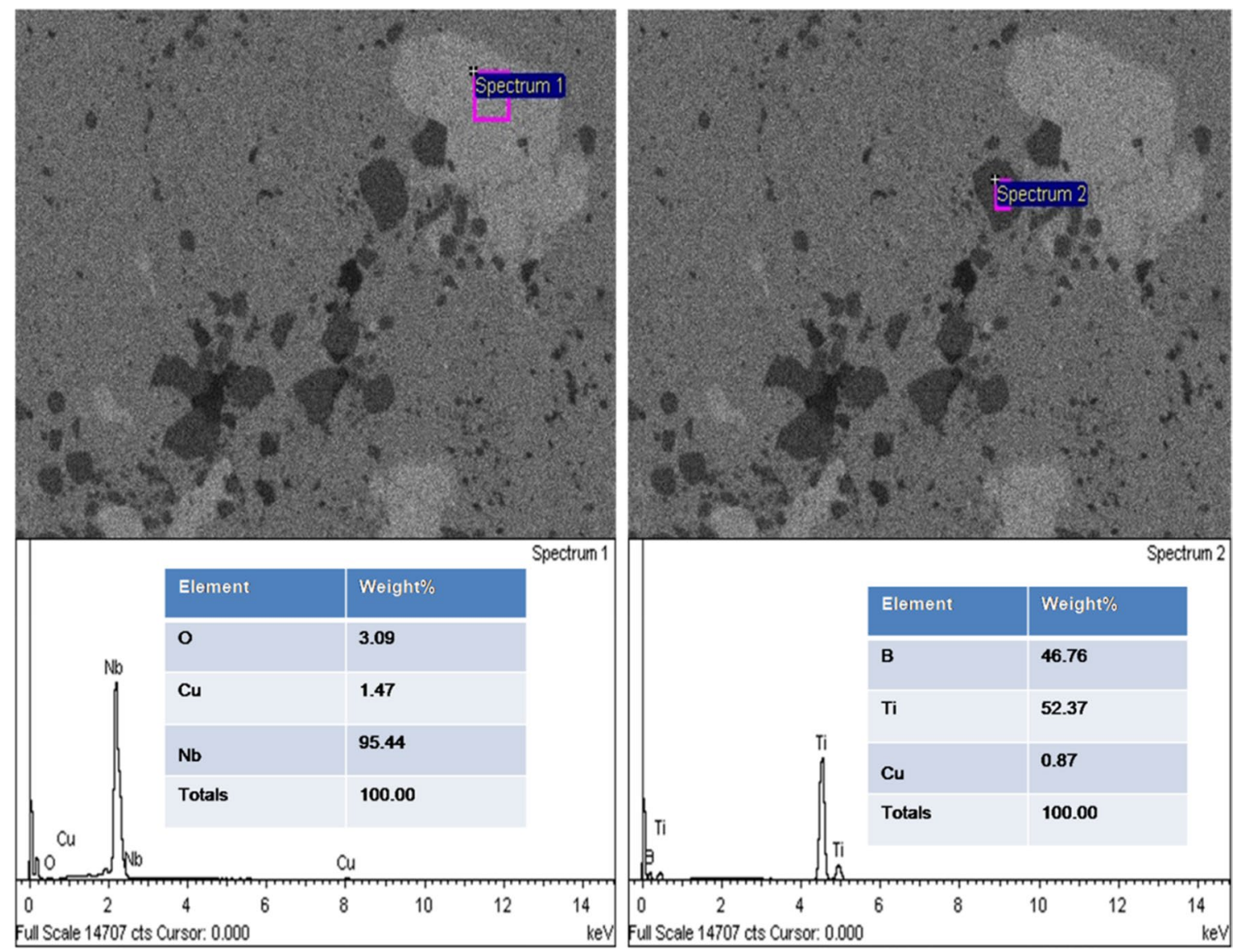

Fig. 9 SEM images and EDS analysis of CuNbTiB2 composite sintered at $700^{\circ} \mathrm{C}$ showing 1 and 2 peaks

respectively. However, the sample (2 specimens) was sintered at two different sintering temperatures. The sample sintered at $700{ }^{\circ} \mathrm{C}$ recorded a higher microhardness value of $940.8 \mathrm{MPa}$ when compared with the one that was sintered at $650^{\circ} \mathrm{C}$, which recorded $827.3 \mathrm{MPa}$. The higher density and relative density values recorded by the sample sintered at $650{ }^{\circ} \mathrm{C}$ might have been influenced by $\mathrm{Cu}$ particles. At the lower temperature of $650{ }^{\circ} \mathrm{C}, \mathrm{Nb}$ and $\mathrm{TiB}_{2}$ particles might not have been precipitated out in the Cu matrix, to create more pores. The higher microhardness value observed in the sample sintered at $700{ }^{\circ} \mathrm{C}$ is expected to be influenced by the precipitation of $\mathrm{Nb}$ and $\mathrm{TiB}_{2}$, as hard materials. The precipitation of $\mathrm{Nb}$ and $\mathrm{TiB}_{2}$ at the sintered temperature of $700{ }^{\circ} \mathrm{C}$ might have formed closely parked particles that could hinder dislocations. Thus, the Orowan strengthening, caused by the resistance of the closely parked hard particles to the passing of dislocations, is widely acknowledged as the strengthening mechanism in metal matrix micro/nanocomposite $[8,17]$.

\subsection{Coefficient of thermal expansion (CTE)}

Figure 11 shows the CTE of the sintered sample $\left(\mathrm{CuNbTiB}_{2}\right)$ at two different temperatures of $650^{\circ} \mathrm{C}$ and $700{ }^{\circ} \mathrm{C}$. Both samples sintered at $650^{\circ} \mathrm{C}$ and $700^{\circ} \mathrm{C}$, showed negative thermal expansion (NTE). At a sintering temperature of $700{ }^{\circ} \mathrm{C}, \mathrm{CUNbTiB}_{2}$ recorded a NTE value of $-7.780 \times 10^{-6}{ }^{\circ} \mathrm{C}^{-1}$ and $-1.375 \times 10^{-5}{ }^{\circ} \mathrm{C}^{-1}$ at a temperature of $650^{\circ} \mathrm{C}$. The negative thermal expansion values indicate contractions of materials when subjected to heat, rather than expansion. In this study, the NTE values obtained showed that the $\mathrm{CuNbTiB}_{2}$ composite contracted upon heating. The presence of $\mathrm{Nb}-\mathrm{O}-\mathrm{Nb}$ bonds, $\mathrm{O}-\mathrm{Cu}-\mathrm{O}$ bonds, and $\mathrm{TiO}_{x}$ $(x=6)$ in the $\mathrm{CuNbTiB}_{2}$ composite (Figs. $\left.5,6,7,8,9,10\right)$ are believed to be responsible for the NTE observed in this study. The greater parts of the crystal structures of NTE materials, have a general feature of two organize metal-oxygen-metal bonds ( $\mathrm{M}-\mathrm{O}-\mathrm{M}$ bond) for the positive ion polyhedral that builds a 3-dimensional lattice. The transverse vibration about an $\mathrm{M}_{1}-\mathrm{O}-\mathrm{M}_{2}$ linkage is the key 

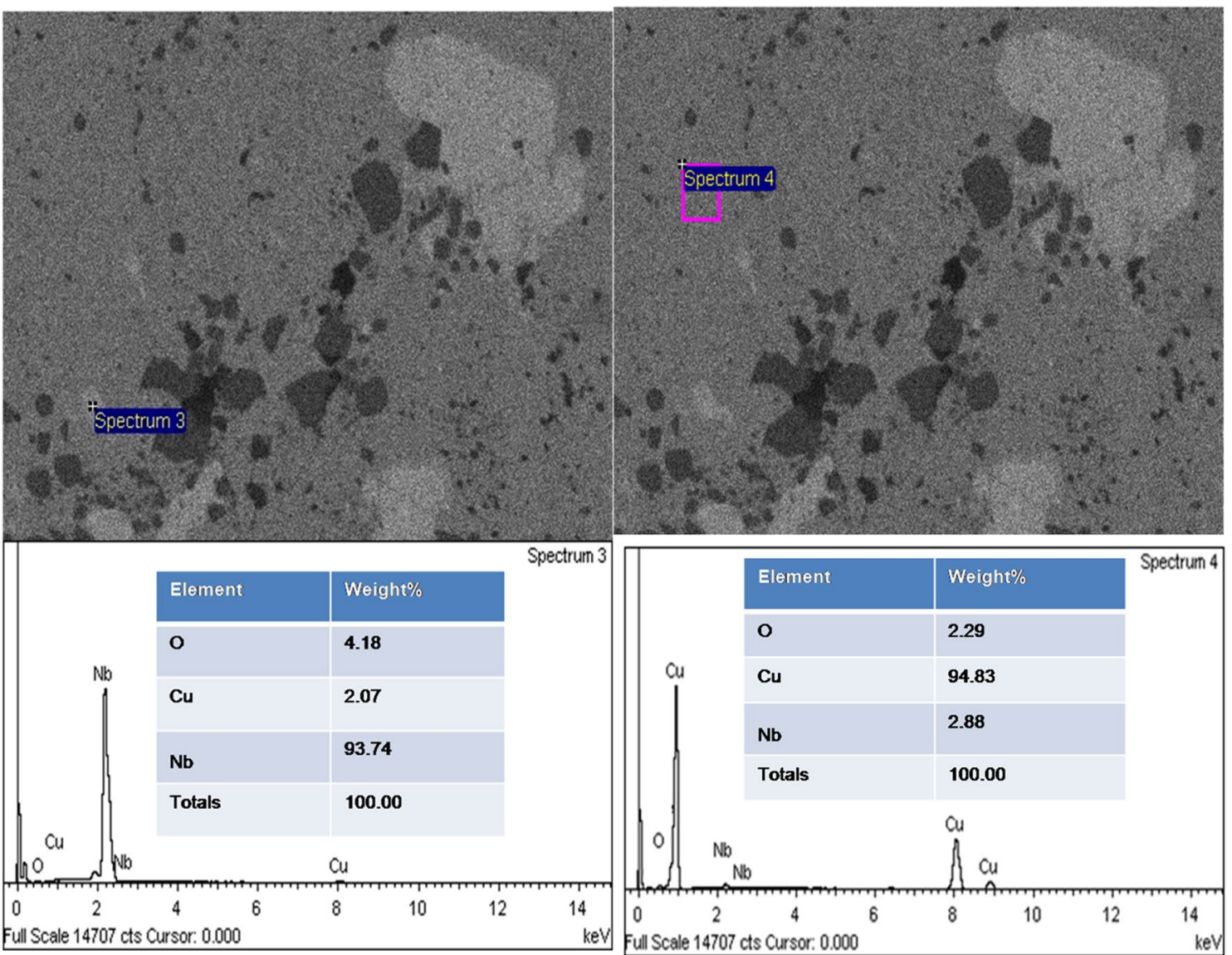

Fig. 10 SEM images and EDS analysis of $\mathrm{CuNbTiB}_{2}$ composite sintered at $700^{\circ} \mathrm{C}$ showing 3 and 4 peaks

Table 2 Summary of the final density, relative density, theoretical density, and microhardness of the $\mathrm{CuNbTiB}_{2}$ sintered composite

\begin{tabular}{llll}
\hline $\begin{array}{l}\text { Sintered Temp. } \\
{ }^{\circ} \mathrm{C}\end{array}$ & $\begin{array}{l}\text { Final density g/ } \\
\mathrm{cm}^{3}\end{array}$ & $\begin{array}{l}\text { Relative density } \\
(\%)\end{array}$ & $\begin{array}{l}\text { Micro-hard- } \\
\text { ness value } \\
(\mathrm{MPa})\end{array}$ \\
\hline 650 & 7.605 & $88.4 \%$ & 827.3 \\
700 & 7.556 & $87.9 \%$ & 940.8 \\
\hline
\end{tabular}

factor for the occurrence of NTE with open-frame-work structure and form a strong bond of $\mathrm{M}_{1}-\mathrm{O}-\mathrm{M}_{2}$ linkage; the length of the $M_{1}-M_{2}$ contracts by the transverse vibrations of oxygen [32]. For approximately linear $\mathrm{M}-\mathrm{O}-\mathrm{M}$ linkages, this process leads to a reduction of the second-nearestneighbor distances and this can result in linear or volume NTE [33]. There have been reports of materials where the NTE takes place by using the oxygen-metal-oxygen (O-M-O) configuration, instead of the metal-oxygenmetal (M-O-M) bond, and an example of such materials is $\mathrm{CuO}_{2}$ (Cuprite), which has an NTE value of $-8 \times 10^{6} \mathrm{~K}^{-1}$ at a temperature below $225 \mathrm{~K}[29,31]$.In the cuprite structure and with its linear $\mathrm{O}-\mathrm{Cu}-\mathrm{O}$ bonds, the bridging copper has the potential of performing transverse 'guitar string'

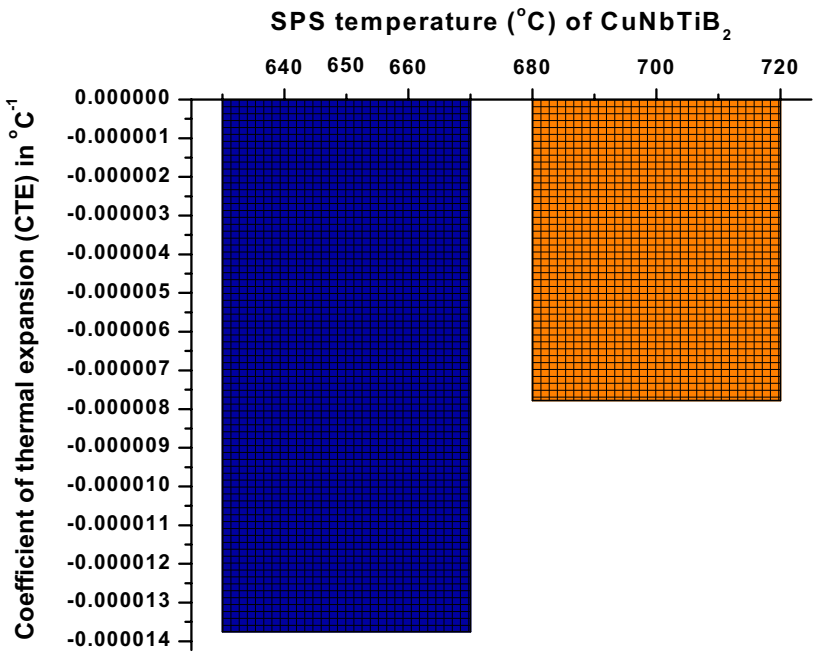

Fig. 11 Negative thermal expansion (NTE) of $\mathrm{CuNbTiB}_{2}$ at $650{ }^{\circ} \mathrm{C}$ and $700{ }^{\circ} \mathrm{C}$

vibrations that give rise to the rotation of $\mathrm{OCu}_{4}$ tetrahedral and hence, leading to the shortenings of the $\mathrm{O}-\mathrm{O}$ distances (negative thermal expansion) [31].There is another 
report that at room temperature, the $\mathrm{TiO}_{6}$ polyhedral bonds are distorted (and thus, the bonds are weaker and longer), but they start to become more regular as heat is applied and this will result in a thermal contraction, which occurs along the crystal axis [29]. However, the presence of niobium oxides $\left(\mathrm{NbO}_{\mathrm{x}}\right)$, copper oxides $\left(\mathrm{CuO}_{\mathrm{x}}\right)$, and titanium oxides $\left(\mathrm{TiO}_{\mathrm{x}}\right)$ contributed, immensely, to the NTE of the CuNbTiB 2 composite (Figs. 5, 6, 7, 8, 9, 10) in this study. It was recorded in the work of Amos [34] that at $327^{\circ} \mathrm{C}$, niobium was displaced in length by $\sim 0.318 \AA$ from the octahedron centered structure and the dilatometer measurement showed negative thermal expansion, associated with temperatures above $200^{\circ} \mathrm{C}$. There are previous works that also demonstrated the NTE behavior of $\mathrm{Nb}_{2} \mathrm{O}_{5}$ in the temperature range of between $20^{\circ} \mathrm{C}$ and $1000^{\circ} \mathrm{C}[35,36]$. Besides, another report demonstrated a negative thermal expansion of $\mathrm{Nb}_{2} \mathrm{O}_{5}$ at relatively high temperatures, even as high as $500{ }^{\circ} \mathrm{C}[28,30]$, which was attributed to the recombination of the micro-crack network, formed during cooling [37]. The new $\mathrm{CuNbTiB}_{2}$ composite produced in this work has many relevancies; as an NTE material. It can be used to control both the physical properties and the thermal expansion of functional materials, such as superconductors, semiconductors, ferroelectrics, magnetic, and Mott insulators [32]. This is so since difficulties attributed to thermal expansion control are universal. These challenges are difficult to resolve and the core technology of thermal expansion control is the negative thermal expansion (NTE) of the materials in question [38].

\subsection{Corrosion studies of sintered samples, in $\mathbf{1} \mathrm{mol}$ $\mathrm{H}_{2} \mathrm{SO}_{4}$ acid}

Figure 12 shows the potentiodynamic polarization curves, which were determined for the $\mathrm{CuNbTiB}_{2}$ composites

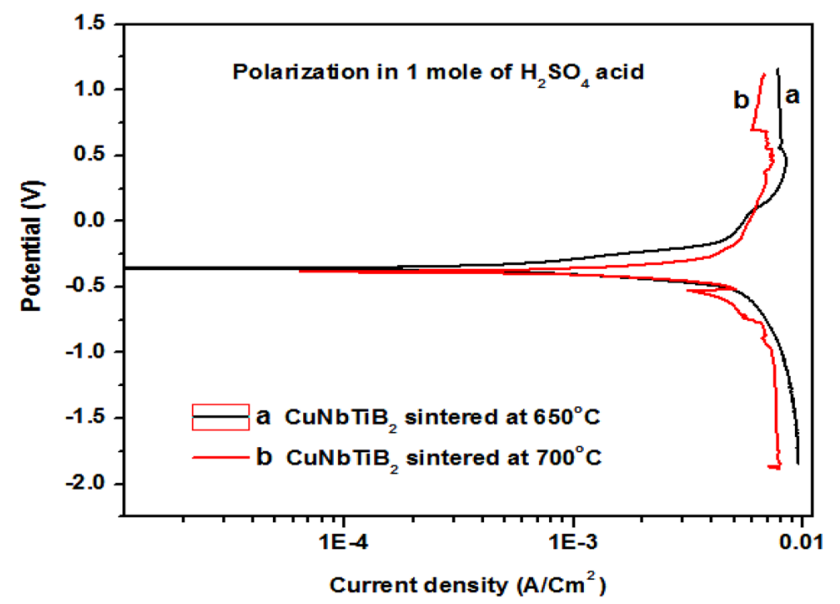

Fig. 12 Polarization curves in $1 \mathrm{~mol}$ of $\mathrm{H}_{2} \mathrm{SO}_{4}$ acid of $\mathrm{CuNbTiB}_{2}$ sintered composite sintered at $650^{\circ} \mathrm{C}$ and $700^{\circ} \mathrm{C}$. In Fig. 12 , it can be seen that the sintered sample at $700^{\circ} \mathrm{C}$, exhibits a reduction in both the current density and the active-zone-line slope when compared with the sintered sample at $650^{\circ} \mathrm{C}$. From the electrochemical theories, it is known that the corrosion rate is directly proportional to the corrosion current density and that a reduction of the corrosion current density will enhance the passivity of the alloys or composites [39]. Based on these facts, it can be inferred that the $\mathrm{CuNbTiB}_{2}$ composite, sintered at $700^{\circ} \mathrm{C}$, exhibited better corrosion resistance than that sintered at $650^{\circ} \mathrm{C}$, due to the possible formation of protective oxide films, which hindered the instigation of pitting.

Figure 13 shows the variation in open circuit potential $(\mathrm{OCP})$ as a function of time for the $\mathrm{CuNbTiB}_{2}$ composites, sintered at $650{ }^{\circ} \mathrm{C}$ and $700{ }^{\circ} \mathrm{C}$, in a 1 -mol sulphuric acid environment. The OCP measurement shows the reactivity or tendency of the sintered samples to corrode in $1 \mathrm{~mol}$ $\mathrm{H}_{2} \mathrm{SO}_{4}$ acid environment with time. The variation in the OCP values of the sintered composite at $650^{\circ} \mathrm{C}$ and $700^{\circ} \mathrm{C}$ was examined at zero applied currents without delay after the immersion of the sintered composites in the acid solution for one hour ( $1 \mathrm{hr}$ ). The potential of the sample sintered at $700{ }^{\circ} \mathrm{C}$ was observed, at the initial stage, to have shifted toward positive values, which later started dropping toward a negative direction with time. On the other hand, the potential of the sample sintered at $650^{\circ} \mathrm{C}$ was observed to shift towards the negative values at the initial stage and was observed to have maintained relative stability as time progressed. After the initial stages, with time, stable passive films were formed on the surface of the samples for composites sintered at both temperatures. At the initial stages, the samples showed that there was a breakdown in the films on their reacting surfaces, followed

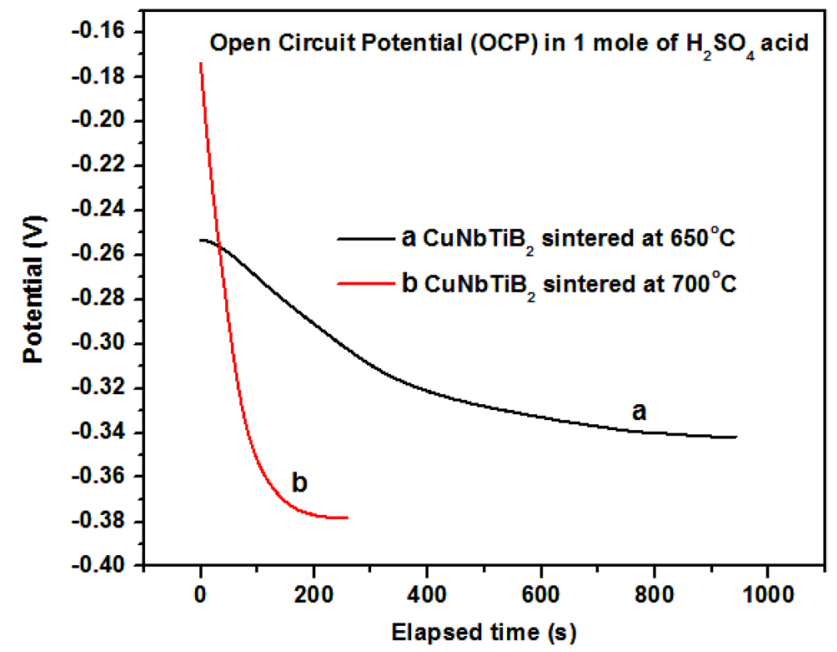

Fig. $13 \mathrm{OCP}$ in $1 \mathrm{~mol}$ of $\mathrm{H}_{2} \mathrm{SO}_{4}$ acid of $\mathrm{CuNbTiB}_{2}$ sintered composite 
by the creation of new passive films, after dissolution. Sample sintered at $700{ }^{\circ} \mathrm{C}$ was observed to show the higher potential values, which established why it exhibited the lowest corrosion rate in the potentiodynamic polarization examination (Fig. 12). Niobium (Nb) and titanium-diboride $\left(\mathrm{TiB}_{2}\right)$ have been known to have good corrosion resistance properties. At a sintering temperature of $700^{\circ} \mathrm{C}$, it is assumed that more $\mathrm{Nb}$ and $\mathrm{TiB}_{2}$ would have precipitated out in the matrix more than experienced at the sintering temperature of $650^{\circ} \mathrm{C}$. This is likely the reason why the sample sintered at $700{ }^{\circ} \mathrm{C}$ performed better in corrosion resistance than the sample sintered at $650^{\circ} \mathrm{C}$.

\section{Conclusions}

This study has investigated the effect of varying the sintering temperatures $\left(650^{\circ} \mathrm{C}\right.$ and $\left.700{ }^{\circ} \mathrm{C}\right)$ on the microstructure, corrosion resistance in a $1 \mathrm{~mol} \mathrm{H}_{2} \mathrm{SO}_{4}$ acid, thermal expansion, and mechanical properties of an in-situ ${ }_{90} \mathrm{Cu}{ }_{6} \mathrm{Nb}-{ }_{4} \mathrm{TiB}_{2}$ powdered composite by using the spark plasma sintering technique. This was studied in detail with the following concise results:

- The study shows that the sintering at a temperature of $700{ }^{\circ} \mathrm{C}$, reduced the displacement rate of the powders with lower density and relative density values when compared with the $650^{\circ} \mathrm{C}$ sintering temperature.

- The microhardness value of the sample sintered at $700{ }^{\circ} \mathrm{C}$ was higher when compared with the one sintered at $650^{\circ} \mathrm{C}$; this is expected due to the precipitation of $\mathrm{Nb}$ and $\mathrm{TiB}_{2}$ particles in the matrix of $\mathrm{Cu}$.

- It was found that the novel composite produced in this work, resulted in a negative thermal expansion (NTE) material at both temperatures of $650^{\circ} \mathrm{C}$ and $700{ }^{\circ} \mathrm{C}$.

- The corrosion resistance of the sample sintered at $700{ }^{\circ} \mathrm{C}$ was better when compared with that sintered at $650^{\circ} \mathrm{C}$.

This study has shown that the varying of the sintering temperatures has an effect on the properties of the composites under study.

A novel composite material of high technological/ scientific value was produced. It can be used to control the mechanical and electrical properties, and the thermal expansion of functional materials, such as superconductors, semiconductors, ferroelectrics, magnetic, and Mott insulators, etc.

However, further studies are recommended to explore more the vital properties of this novel composite material.

Acknowledgements The authors acknowledge the Department of Science and Technology (DST), South Africa for financial support.

\section{Compliance with ethical standards}

Conflict of interest The authors declare that they have no known competing financial interests or personal relationships that could have appeared to influence the work reported in this paper.

\section{References}

1. Morris D, Morris M (1990) Mechanical alloying of copper-BCC element mixtures. Scr Metall Mater 24:1701-1706

2. Eze A, Jamiru T, Sadiku E, Diouf S, Durowoju M, Ibrahim I et al (2017) Electrical conductivity of Cu and Cu-2vol.\% Nb powders and the effect of varying sintering temperatures on their mechanical properties using spark plasma sintering. Silicon 9:855-65

3. Eze AA (2016) Production of binary copper-titanium and copper-niobium alloys for trolley wire applications using spark plasma sintering techniques spark plasma sintering techniques. Tshwane University of Technology, Pretoria

4. Eze AA (2019) Development of a new copper-niobium based composite trolley cable for electric trains. Tshwane University of Technology, Pretoria

5. Eze AA, Jamiru T, Sadiku ER, Durowoju MO, Kupolati WK, Ibrahim ID (2019) Considering the use of niobium and titanium to enhance electrical and mechanical properties of copper at higher operational temperature application. SN Appl Sci 1:74

6. Raabe D, Heringhaus F, Hangen U, Gottstein G (1995) Investigation of a Cu-20 mass\% Nb in situ composite, part I: fabrication, microstructure and mechanical properties. Zeitschrift fur Metallkunde 86:405-415

7. Balaji R, Babu SVS, Channankaiah D (2014) Wear behaviour of sintered titanium diboride reinforced graphite aluminium composites. Int J Eng Res Technol. 3

8. Durowoju M, Sadiku E, Diouf S, Shongwe M, Makena I, Ramakokovhu $\mathrm{M}$ et al (2019) Wear and corrosion studies of graphitealuminum composite reinforced with micro/nano- $\mathrm{TiB}_{2}$ via spark plasma sintering. Mater Werkst 50:126-139

9. Pavlík V, Boča M (2012) Corrosion of titanium diboride in molten FLiNaK (eut). Chem Pap 66:1073-1077

10. Guo Z, Li N, Hu J (2015) Cu-TiB metal matrix composites prepared by powder metallurgy route. Sci Sinter 47:165-174

11. Legoux J, Dallaire S (1993) Copper-titanium diboride coatings obtained by plasma spraying reactive micropellets. J Therm Spray Technol 2:283-286

12. Park J, Yun J, Park YD, Park YH, Cho KM, Park IM (2007) Effect of cooling rate on mechanical and electrical properties of $\mathrm{Cu}-\mathrm{TiB}_{2}$ by turbulent in-situ mixing process. Solid State Phenom Trans Tech Publ 119:135-8

13. Tu JP, Rong W, Guo SY, Yang YZ (2003) Dry sliding wear behavior of in situ $\mathrm{Cu}-\mathrm{TiB}_{2}$ nanocomposites against medium carbon steel. Wear 255:832-835

14. $\mathrm{Xu} \mathrm{L}$, Han JC, Zhang $\mathrm{XH}$ (2007) Defect and its influence on mechanical property of titanium diboride-copper matrix composite. Key Eng Mater Trans Tech Publ 336:1414-6

15. Xu Q, Zhang XH, Han JC, Pan W (2005) Effect of copper content on the microstructures and properties of $\mathrm{TiB}_{2}$ based cermets by SHS. Mater Sci Forum Trans Tech Publ 475:1619-22

16. Balbo A, Monticelli C, Bellosi A, Pagnoni A (2002) Corrosion of alumina/titanium diboride composites in neutral and acidic chloride solutions. Mater Corros 53:471-478

17. Monticelli C, Frignani A, Bellosi A, Brunoro G, Trabanelli G (2001) The corrosion behaviour of titanium diboride in neutral chloride solution. Corros Sci 43:979-992 
18. Ankem S, Margolin H, Greene CA, Neuberger BW, Oberson PG (2006) Mechanical properties of alloys consisting of two ductile phases. Prog Mater Sci 51:632-709

19. Bellosi A, Monteverde F, Sciti D (2006) Fast densification of ultrahigh-temperature ceramics by spark plasma sintering. Int J Appl Ceram Technol 3:32-40

20. Durowoju M, Sadiku E, Diouf S, Shongwe M, Olubambi PA (2015) Spark plasma sintering of graphite-aluminum powder reinforced with SiC/Si particles. Powder Technol 284:504-513

21. Hungria T, Galy J, Castro A (2009) Spark plasma sintering as a useful technique to the nanostructuration of piezo-ferroelectric materials. Adv Eng Mater 11:615-631

22. Saheb N, Iqbal Z, Khalil A, Hakeem AS, Al Aqeeli N, Laoui $T$ et al (2012) Spark plasma sintering of metals and metal matrix nanocomposites: a review. J Nanomater. https://doi. org/10.1155/2012/983470

23. Zhang F, Reich M, Kessler O, Burkel E (2013) The potential of rapid cooling spark plasma sintering for metallic materials. Mater Today 16:192-197

24. Ghasali E, Palizdar Y, Jam A, Rajaei H, Ebadzadeh T (2017) Effect of $\mathrm{Al}$ and Mo addition on phase formation, mechanical and microstructure properties of spark plasma sintered iron alloy. Mater Today Commun 13:221-231

25. Diouf S, Molinari A (2012) Densification mechanisms in spark plasma sintering: effect of particle size and pressure. Powder Technol 221:220-227

26. Walker LS, Pinc WR, Corral EL (2012) Powder processing effects on the rapid low-temperature densification of $\mathrm{ZrB}_{2}-\mathrm{SiC}$ ultrahigh temperature ceramic composites using spark plasma sintering. J Am Ceram Soc 95:194-203

27. Fogagnolo J, Robert M, Ruiz-Navas E, Torralba J (2004) 6061 Al reinforced with zirconium diboride particles processed by conventional powder metallurgy and mechanical alloying. J Mater Sci 39:127-132

28. Choosuwan H, Guo R, Bhalla A, Balachandran U (2002) Negative thermal expansion behavior in single crystal and ceramic of $\mathrm{Nb}_{2} \mathrm{O}_{5}$-based compositions. J Appl Phys 91:5051-5054
29. Grima JN, Zammit V, Gatt R (2006) Negative thermal expansion

30. Palatnikov M, Shcherbina O, Frolov A, Pavlikov V, Karpets $M$, Makarova $O$ et al (2010) Effect of high-intensity light on the micro-and nanostructuring and thermal expansion of $\mathrm{Ta}_{2} \mathrm{O}_{5}$ and $\mathrm{Nb}_{2} \mathrm{O}_{5}$ ceramics. Inorg Mater 46:683-690

31. Schäfer W, Kirfel A (2002) Neutron powder diffraction study of the thermal expansion of cuprite. Appl Phys A 74:s1010-s1012

32. Chen J, Hu L, Deng J, Xing X (2015) Negative thermal expansion in functional materials: controllable thermal expansion by chemical modifications. Chem Soc Rev 44:3522-3567

33. Lind C (2012) Two decades of negative thermal expansion research: where do we stand? Materials 5:1125-1154

34. Amos TG. Negative thermal expansion in $\mathrm{AOMO}_{4}$ compounds. 2000.

35. Douglass D (1963) The thermal expansion of niobium pentoxide and its effect on the spalling of niobium oxidation films. J Less Common Metals 5:151-157

36. Dwivedi G, Subbarao E (1973) Thermal expansion of monoclinic (alpha) Nb 2 O 5. J Amer Ceram Soc 56:443-444

37. Rani RA, Zoolfakar AS, O'Mullane AP, Austin MW, Kalantar-Zadeh K (2014) Thin films and nanostructures of niobium pentoxide: fundamental properties, synthesis methods and applications. J Mater Chem A 2:15683-15703

38. Takenaka K (2018) Progress of research in negative thermal expansion materials: paradigm shift in the control of thermal expansion. Front Chem 6:267

39. Popoola A, Pityana S, Popoola O (2011) Microstructure and corrosion properties of $\mathrm{Al}\left(\mathrm{Ni} / \mathrm{TiB}_{2}\right)$ intermetallic matrix composite coatings. J South Afr Inst Min Metall 111:345-353

Publisher's Note Springer Nature remains neutral with regard to jurisdictional claims in published maps and institutional affiliations. 